\title{
EFFECT OF BIOFERTILIZERS AND PLANT GROWTH PROMOTING BACTERIA ON THE GROWTH CHARACTERISTICS OF THE HERB ASPARAGUS OFFICINALIS
}

\author{
GE, C. ${ }^{1}-$ RADNEZHAD, H. ${ }^{2, *}-$ ABARI, M. F. ${ }^{2}-$ SADEGHI, M. ${ }^{2}-$ KASHI, G. ${ }^{3}$ \\ ${ }^{1}$ Department of Biological and Environment Engineering, Hefei University, Hefei, 230000, \\ China \\ ${ }^{2}$ Department of Environmental Sciences, Isfahan (Khorasgan) branch, Islamic Azad University, \\ Isfahan, Iran \\ ${ }^{3}$ Department of Environmental Health, School of Health, Islamic Azad University Tehran \\ Medical Sciences Branch, Tehran, Iran \\ *Corresponding author \\ e-mail:hradnezhad@yahoo.com \\ (Received $11^{\text {th }}$ Oct 2015; accepted 23 $3^{\text {rd }}$ May 2016)
}

\begin{abstract}
The purpose of this research was to investigate the effects of applying vermicompost, Nitroxin and cow manure on the growth characteristics of Asparagus officinalis L. Significant differences in germination percentage were observed between fertilizer treatments with control. Vermicompost was more efficient at lower concentrations and in non-combined treatment, but higher effects were resulted from the mixture of cow manure with Nitroxin and also higher concentrations. The maximum means of germination time and germination rate were related to the treatments of $15 \%$ and $30 \%$ vermicompost, and cow manure mixed with Nitroxin. The higher effects and significant differences of root and shoot length were related to treatment of $15 \%$ vermicompost, however the comparison of the combined and noncombined treatments of vermicompost showed higher effect by the mixture of $30 \%$, moreover, these treatments enhanced the length of root and shoot. Significant differences and higher effects on root fresh weight were induced by treatment with $15 \%$ vermicompost, but the dry weight of root and fresh and dry weight of shoot showed significant differences and higher effects by the treatment with $30 \%$ vermicompost mixed with Nitroxin. All treatments have affected positively the dry weight of root and fresh and dry weight of shoot.
\end{abstract}

Keywords: cow manure, germination percentage, growth characteristics, Nitroxin, vermicompost

\section{Introduction}

Intensive farming practices, that warrant high yield and quality, require the extensive use of chemical fertilizers, which are costly and create environmental problems. Therefore, more recently there has been a resurgence of interest in environmental friendly, sustainable and organic agricultural practices (Esitken et al., 2005). Organic agriculture is a production system, which avoids or largely excludes the use of synthetically compounded fertilizers, and, as far as possible, organic agricultural systems rely upon bio-fertilization, however yield reduction is an important problem in organic production system (Lind et al., 2003). Using biofertilizers containing beneficial microorganisms instead of synthetic chemical improve plant growth through supplying plant nutrients and may help to sustain environmental health and soil productivity (O'Connell, 1992). So far considerable number of bacterial species, mostly associated with the plant rhizosphere, were tested and found to be beneficial for plant growth, yield and crop quality. They have been called 'plant growth promoting rhizobacteria (PGPR)' 
including the strains in the genera Azospirillium, Azotobacter, (Rodriguez and Fraga, 1999; Sturz and Nowak, 2000; Sudhakar., et al., 2000). PGPR participates in many key ecosystem processes, such as those involved in the biological control of plant pathogens, $\mathrm{N}$ fixation, solubilisation of nutrients and phytohormone synthesis (Vessey, 2003). Vermicomposts, which are stabilized organic materials produced by interactions between earthworms and microorganisms in a non-thermophilic process, have been reported to enhance plant germination growth and yields in greenhouse crops (Edwards and Burrows, 1988; Buckerfield et al., 1999; Atiyeh et al., 2000, 2001; Edwards et al., 2004). Such increasing productivity of crops, in response to vermicomposts amendments, have been attributed to the greater availability of mineral nutrients, than in commercial plant growth media containing only inorganic nutrients (Edwards and Burrows, 1988; Werner and Cuevas, 1996), as well as their rich microbial populations (Edwards, 1983; Tomati et al., 1987). The presence of plant growth-influencing substances, such as plant growth hormones and humic acids in vermicomposts has also been suggested as a possible factor contributing to increased plant growth and yields (Arancon et al., 2003). Gupta et al. (2014) showed that the addition of vermicompost, in appropriate quantities, to potting media had significantly positive effects on growth and flowering of marigold seedlings including plant biomass, plant height, the number of buds and flowers. Subler et al. (1998) reported that optimum plant growth responses occurred when 10-20\% vermicompost was amended with potting media which may be due to enhanced micronutrient availability, the presence of plant growth regulators, or the activity of beneficial microorganisms in the vermicompost, however when the vermicompost concentration was $>40 \%$ in the potting media then the number and diameter of the flowers reduced than control. These antagonistic effects at higher vermicomposts dosage may be due to reduction in aeration and porosity and increased salt concentrations (Tucker, 2005). Yadav and Garg (2015) stated that the seed germination is an important and decisive phase in growth cycle of a plant since it determines plant establishment and yield, while the several authors have reported moderate or no effect of vermicompost on seed germination (Singh et al., 2013; Roy et al., 2010; Alves and Passoni, 1997). In contrast, Ievinsh (2011) has reported that vermicompost addition inhibits seed germination depending on crop species and cultivar tested even at moderate concentrations.

The objectives of this research were the comparison of the effects of fertilizers such as vermicompost, cow manure and Nitroxin on the growing characteristics of asparagus and the effects of Nitroxin, $15 \%$ and $30 \%$ cow manure, $15 \%$ and $30 \%$ vermicompost, the combination of $15 \%$ and $30 \%$ vermicompost with Nitroxin and the combination of $15 \%$ and $30 \%$ cow manure with Nitroxin on the characteristics of germination percentage, length of root and shoot, and fresh and dry weight of root and shoot, and the mean time of germination and germination rate.

\section{Methods}

\section{Experimental site and material}

This experiment was done on 2013-2014 crops by randomized complete block design with 10 treatments and four replications conducted in pots with the mouth diameter of 15 and height of $19 \mathrm{~cm}$ in the greenhouse of Isfahan (Khorasgan) Branch, Azad University located in Isfahan, Iran. The maximum temperature of day and night were $35^{\circ} \mathrm{C}$ and $10^{\circ} \mathrm{C}$ and the average temperature of day and night were $14^{\circ} \mathrm{C}$ and $25^{\circ} \mathrm{C}$, 
respectively. When the experiment was being conducted in the greenhouse with the conditions listed above, the effects of vermicompost, Nitroxin and cow manure on the herb asparagus (Asparagus officinalis L.) were evaluated. Asparagus officinalis L. is a perennial monocotyledon, a member of the Liliaceae family. It grows in temperate climates and under subtropical conditions. Asparagus requires well-drained loam or sandy-loam soils, or heavier soils where there is good drainage. The soil used in potting media was collected from the agricultural research fields of University of Azad Islamic Khorasgan, Isfahan. The soil was sandy-loam in nature.

\section{Experimental treatments}

At first 40 pots were used for 10 treatments (4 pots per each treatment). The pots 1 to 4 were filled with the sand-soil mixture as control sample (T1), 5 to 8 with $15 \%$ vermicompost and $85 \%$ sand and soil(T2), 9 to 12 with $15 \%$ vermicompost mixed with Nitroxin and $85 \%$ sand and soil (T3), 13 to 16 with $30 \%$ vermicompost and $70 \%$ sand and soil(T4), 17 to 20 with $30 \%$ vermicompost mixed with Nitroxin and $70 \%$ sand and soi(T5), 21 to 24 with Nitroxin and sand and soil(T6), 25 to 28 with $15 \%$ cow manure and $85 \%$ sand and soil (T7), 29 to 32 with $15 \%$ cow manure mixed with Nitroxin and sand and soil (T8), 33 to 36 with 30\% cow manure and 70\% sand and soil(T9), 37 to 40 with 30\% cow manure mixed with Nitroxin and 85\% sand and soil(T10). A certain proportion of sand-soil mixture was used in all substrates. The seeds of asparagus have purchased from Pakan seed Company in Isfahan. The biofertilizer, comprising Azospirillum and Azotobacter, was developed by the soil and water Research Institute (SWRI) in Tehran and now is manufactured under the brand name "Nitroxin" by the private company in Semnan, Iran. The Nitroxin solution was purchased from Agricultural Products Distribution Company. The half of seeds has placed in Nitroxin solution. After filling the pots in the mentioned order, 25 seeds of asparagus were planted in each pot and covered with $1.5 \mathrm{~cm}$ soil. The seeds which were in Nitroxin solution have infused on the soil of all pots. The vermicompost used in potting media were prepared in the research institute of organic waste recycling in the Islamic Azad University of Khorasgan, Isfahan using (a) cow dung and (b) agriculture residue spiked cow dung. The cow manure used in the study was obtained from a local cowshed located about $10 \mathrm{~km}$ North West of the Islamic Azad University of Khorasgan, Isfahan. The Nitroxin was sprayed on the verrmicompost, cow manure and soil of the T3, T5, T6, T8 and T10.

\section{Measuring growth}

Germinated seeds were counted from day 8 in the intervals of 4 day until the end of the experiment (lasted 90 days). At the end, the shoots and roots length $(\mathrm{cm})$ were measured using a transparent ruler. To determine the dry weight, roots and shoots of samples were placed in the oven at $72{ }^{\circ} \mathrm{C}$ for 48 hours, and then the dry weight was measured by a digital scale with a precision of one ten-thousandth of a gram.

Germination percentage was obtained from the ratio of the number of seeds germinated (after 14 days) to the total number of seeds planted in each pot. Germination rate and the mean time to germination were calculated based on Equations 1 and 2, respectively.

$$
R S=\sum_{i=1}^{n} \frac{S i}{D i}
$$


$\mathrm{RS}$ is the germination rate, $\mathrm{Si}$ is the number of germinated seeds of each Counted; Di is days to the counting the $\mathrm{n}$-th and $\mathrm{n}$ is the number of the counting.

Germination percentage (GP) and mean germination time (MGT) for each species and each treatment was calculated according to Equations 2 and 3:

$$
\begin{gathered}
G P(\%)=\sum \frac{n_{\mathrm{i}}}{N \times 100} \\
M G T(\text { days })=\frac{\sum\left(t_{\mathrm{i}} \times n_{\mathrm{i}}\right)}{\sum n_{\mathrm{i}}}
\end{gathered}
$$

$\mathrm{N}_{\mathrm{i}}$ is the number of germinated seeds, $\mathrm{N}$ is the total number of seeds per Petri dish and ti is the number of days since the start of the experiment (Eliss and Robert, 1981).

\section{Data analyses}

The effect of different treatments on the characteristics of germination percentage, length of root and shoot, and fresh and dry weight of root and shoot, and the mean time of germination and germination rate were measured in all substrates (in a biological reaction). The data set was obtained from four replicates in ten treatments. ANOVA was used to evaluate the effect of different treatments on the germination percentage and mean germination time. The means of measured data set were compared by Duncan test. All statistical analyses and the drawing of charts were performed by software SPSS 19. The outcomes were presented as tables and figures.

\section{Results and discussion}

\section{Germination percentage}

The results of all treatments showed significant differences in germination percentage compared with the control one. The highest and lowest effects on the germination were related to the control sample and 15\% cow manure, respectively. Therefore, the used organic fertilizers and biofertilizers inhibited the seed germination of the Asparagus officinalis L. This is in agreement with the findings of Ievinsh (2011). Organic substances needed for seed germination have been isolated from various sources of animal waste composts and identified as phenolic acids (Garraway and Ramirez, 1982; Marambe and Ando, 1992). Marambe et al. (1993), isolated and identified some long-chain fatty acids as strong inhibitory substances for sorghum seed germination in animal-waste compost and reported the mode of action. The germination percentage significantly differed in $15 \%$ and $30 \%$ vermicompost treatments but there was no significant difference when the mixture of vermicompost with Nitroxin was used, however both of them had higher effects on the level of $15 \%$. In this regard, Warman and AngLopez (2010) showed that the percentage of germination increased with the maturation of vermicompost but the addition of vermicompost to the soil or water often resulted in poorer germination compared with the soil or water (only) controls. Nitroxin treatment showed no significant difference compared with treatments by $30 \%$ cow manure and $30 \%$ vermicompost mixed with Nitroxin howbeit, the improved effectiveness of the mixture. Significant differences were observed in the treatments of cow manure and its mix with Nitroxin and greater effect found when the cow manure was mixed with Nitroxin, moreover germination at higher concentrations showed 
an increase (Fig. 1). Zaller (2007), also showed a stimulatory effect on germination when the growth medium was composed of varying proportions of vermicompost mixed with soil. Several studies have related the immaturity of composts to phytotoxic reactions which inhibit or retard seed germination and plant growth (Jimenez and Garcia, 1989; Baca et al., 1990; Warman, 1999b). Warman and AngLopez (2002) reported although little or no work has described such toxic components in vermicompost but surface crusts that were observed on soils containing the greatest amounts of vermicompost could explain the consistently poor germination of all three test species in these soils. The crusting may have limited water infiltration and created anaerobic conditions in the growth mix, which can result in the production of phytotoxic substances. They hypothesize that the organic substances in the vermicomposts may have contributed to phytotoxicity rather than soluble salts in addition; they showed the germination percent reduction of all three test plants with all the vermicomposts in $\% 25 \mathrm{~V}$ compared to $\% 12.5 \mathrm{~V}$ signified greater sensitivity to phytotoxic substances in the vermicompost.

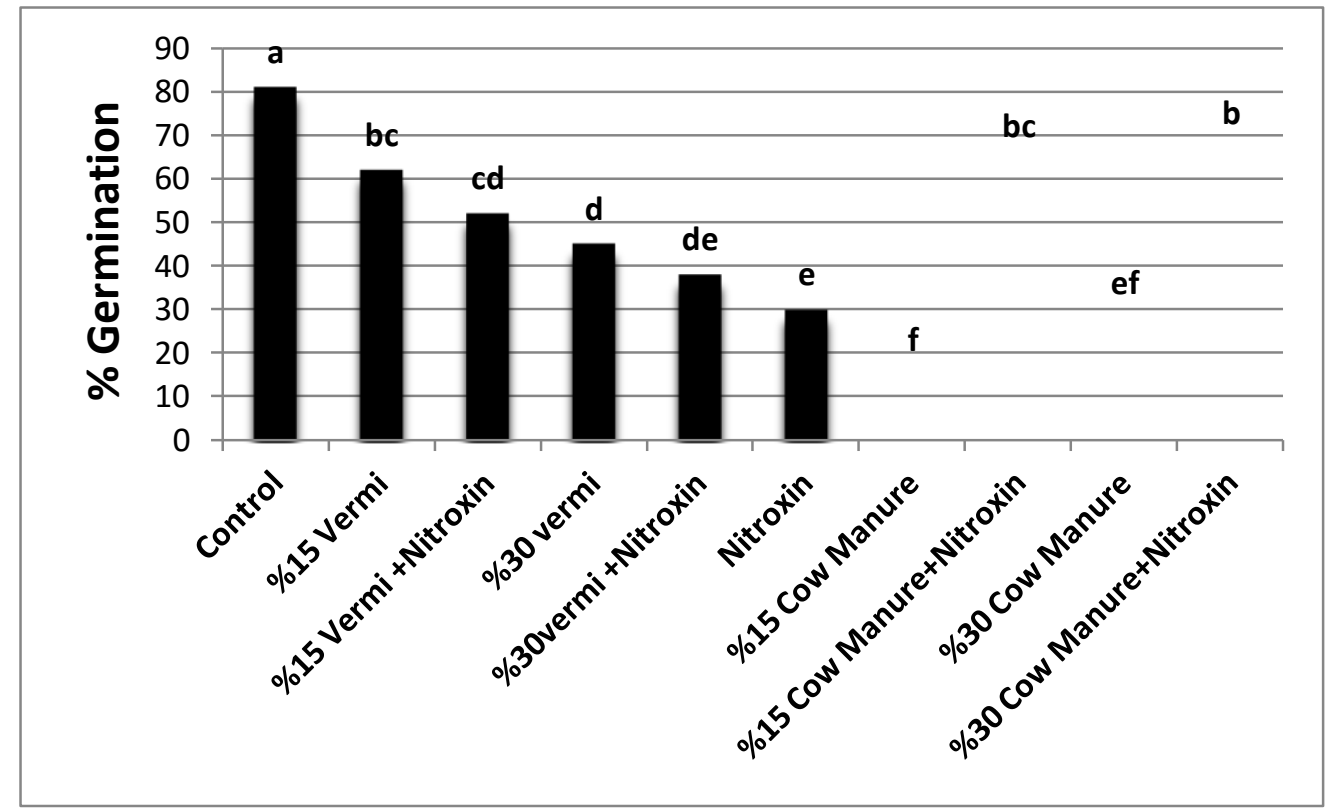

Figure 1. The average of Germination percentage in four replications NOTE: Control $=$ T1, 15\% Vermi $=$ T2, 15\% Vermi. Nitroxin $=T 3$, 30\% Vermi $=$ T4, 30\% Vermi. Nitroxin=T5, Nitroxin=T6, 15\% Cow Manure =T7, 15\% Cow Manure. Nitroxin=T8, 30\% Cow Manure $=$ T9, 30\% Cow Manure. Nitroxin=T10.

\section{The average germination time}

The average germination time showed significant differences between the treatment of $15 \%$ vermicompost and the mixture of $15 \%$ vermicompost with Nitroxin, $15 \%$ cow manure with Nitroxin, and 30\% cow manure. The comparison of treatments showed that only $15 \%$ vermicompost and mixture of $30 \%$ cow manure with Nitroxin treatments increased the mean germination time compared with the control (Fig. 2). This occurred due to the gradual reduction of germination barrier and the release of the germinationpromoting substances. 


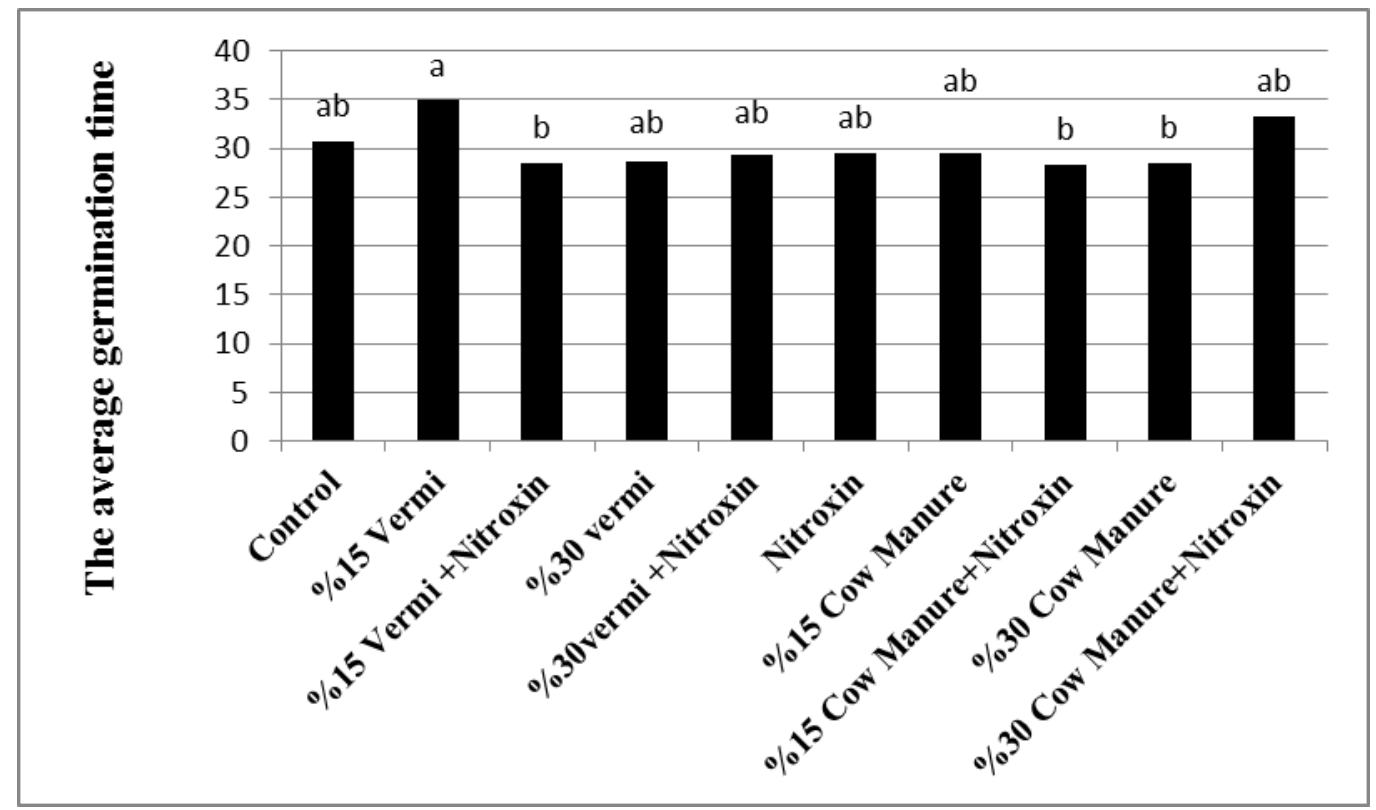

Figure 2. The average of Germination time

NOTE: Control $=$ T1, 15\% Vermi=T2, 15\% Vermi. Nitroxin $=$ T3, 30\% Vermi $=$ T4, $30 \%$ Vermi. Nitroxin=T5, Nitroxin=T6, 15\% Cow Manure=T7, 15\% Cow Manure. Nitroxin=T8, 30\% Cow Manure $=$ T9, 30\% Cow Manure. Nitroxin=T10.

\section{The rate of germination}

The germination rate of fertilizer treatments (Fig. 3) showed that $30 \%$ cow manure mixed with Nitroxin in all time periods had the highest rate of germination and the lowest rate of germination was related to treatment of $15 \%$ cow manure.

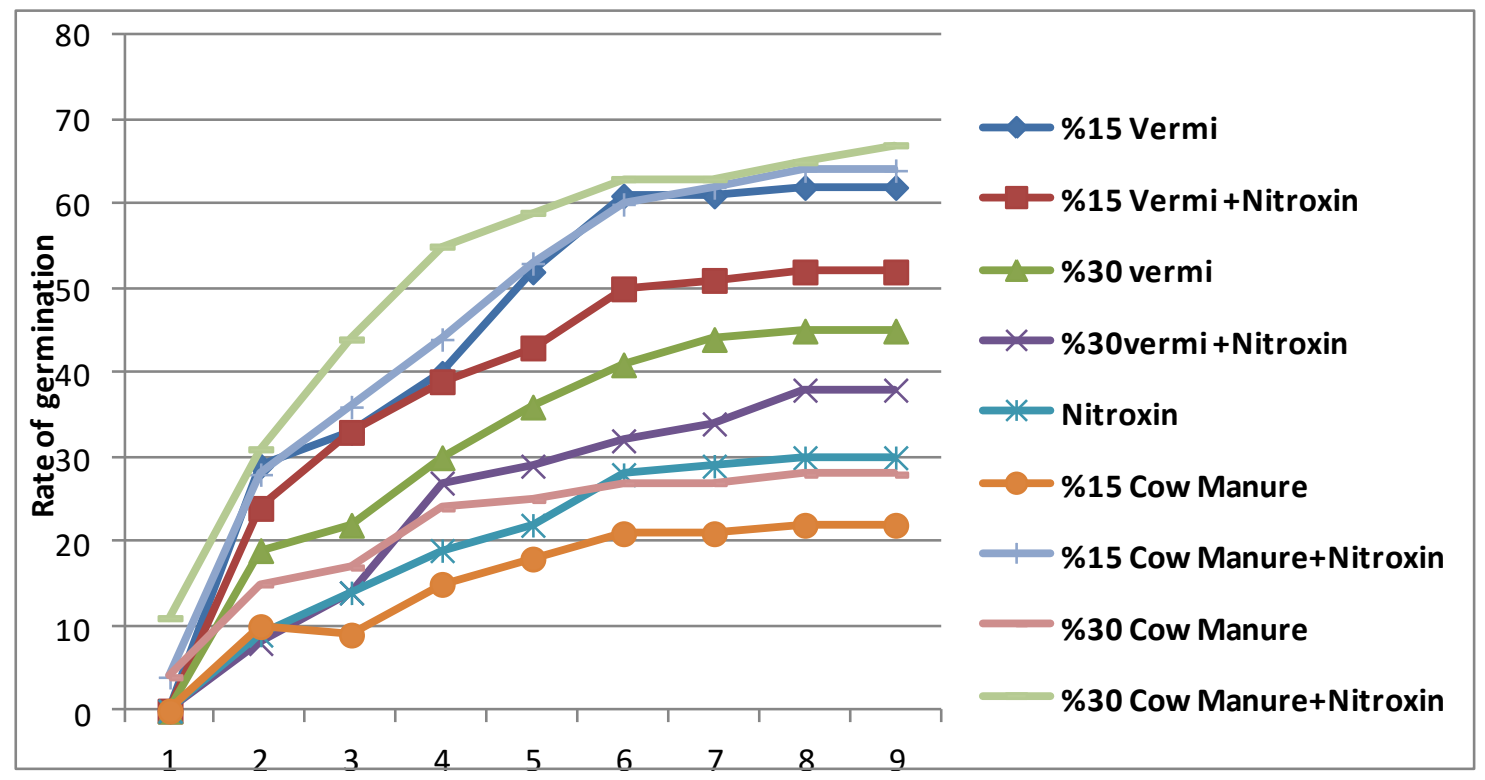

Figure 3. The comparison of Germination rate in different fertilizer treatments

NOTE: Control $=$ T1, 15\% Vermi $=$ T2, 15\%Vermi. Nitroxin $=T 3,30 \%$ Vermi $=$ T4, 30\%Vermi . Nitroxin=T5, Nitroxin=T6, 15\% Cow Manure =T7, 15\% Cow Manure. Nitroxin=T8, 30\% Cow Manure $=$ T9, 30\% Cow Manure. Nitroxin $=$ T10. 


\section{Root and stem length (cm)}

Root length in treatments with $15 \%$ vermicompost and two levels of the $30 \%$ and $15 \%$ vermicompost mixed with Nitroxin made a significant difference to the control and other treatements. 15\% vermicompost and control treatments showed highest and lowest effect on root elongation, respectively. Significant differences were found between using $15 \%$ and $30 \%$ vermicompost as well as between each level with the same level that had been mixed with Nitroxin. The greatest effect on root elongation caused by $15 \%$ vermicompost but its combination with Nitroxin reduced the length of the root while at $30 \%$ level the effect was stronger by mixing. The treatments of Nitroxin, cow manure and cow manure mixed with Nitroxin although were not significantly different compared with the control, but their impact were improved compared with the control (Fig. 4). The results showed significant difference in shoot length between the plants treated with $15 \%$ vermicompost and $30 \%$ vermicompost. The plants treated with 15\% vermicompost and the mixture of $30 \%$ vermicompost with Nitroxin showed significant difference in shoot length with the Control sample. Nitroxin had the lowest effect on shoot length among the other fertilizers and control. The shoot length in the plants treated with Nitroxin showed significant difference with the plants treated with $15 \%$ and $30 \%$ cow manure, cow manure mixed with Nitroxin, $15 \%$ vermicompost, $15 \%$ and $30 \%$ vermicompost mixed with Nitroxin. The stem length increased in the treatments with the $15 \%$ and $30 \%$ vermicompost. While $15 \%$ vermicompost mixed with Nitroxin caused the negative effect on stem elongation compared with non-mixed at this level, at level of the $30 \%$ higher impact was observed by mixed treatment. There was no significant difference between the Nitroxin and control, although Nitroxin made reduction in stem length. Cow manure and its combination with Nitroxin showed more effect compared with the control (Fig. 5).

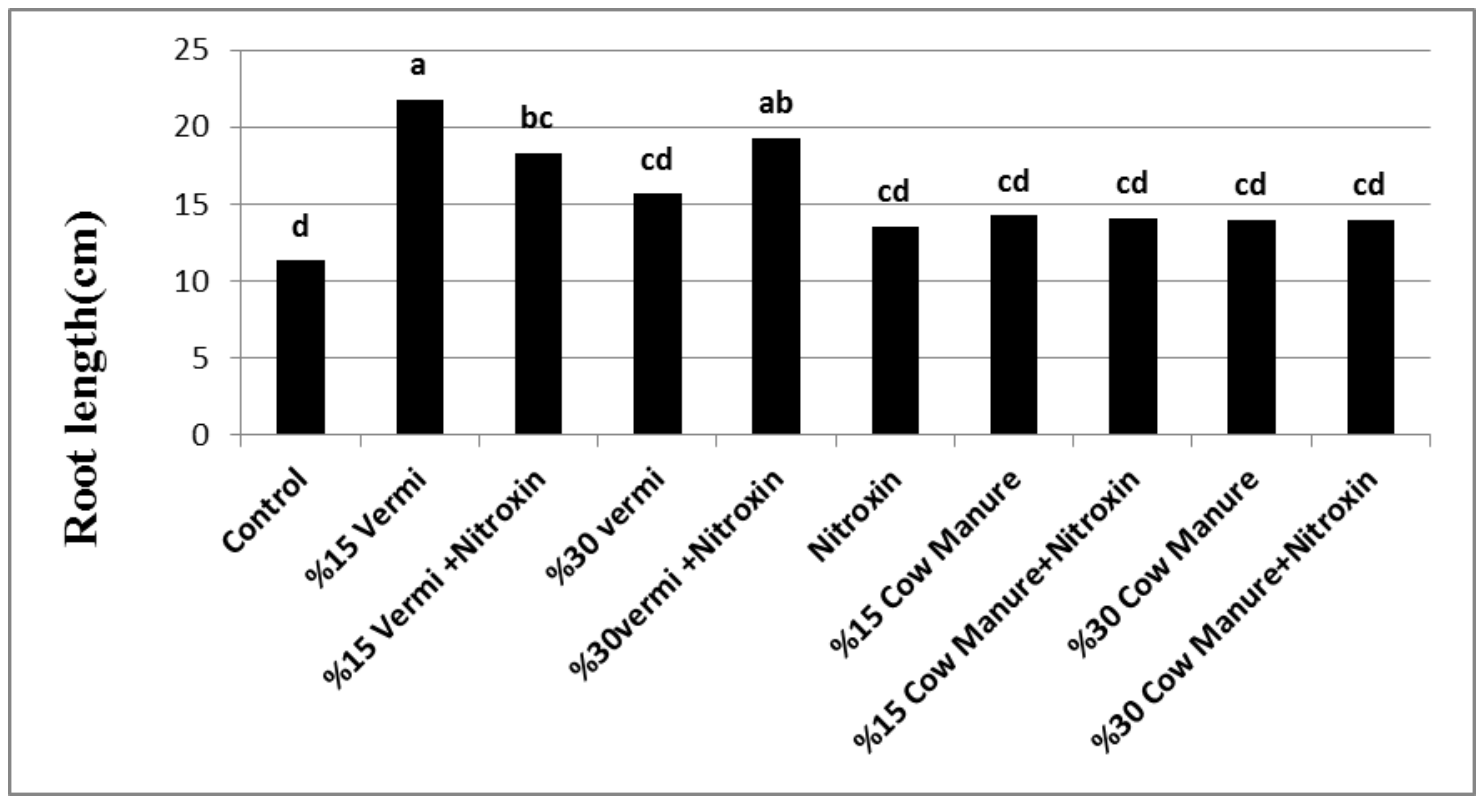

Figure 4. The average of root elongation in four replications

NOTE: Control $=$ T1, 15\% Vermi $=$ T2, 15\%Vermi. Nitroxin $=T 3,30 \%$ Vermi $=$ T4, 30\%Vermi . Nitroxin=T5, Nitroxin=T6, 15\% Cow Manure =T7, 15\% Cow Manure. Nitroxin=T8, 30\% Cow

Manure $=$ T9, 30\% Cow Manure. Nitroxin=T10. 


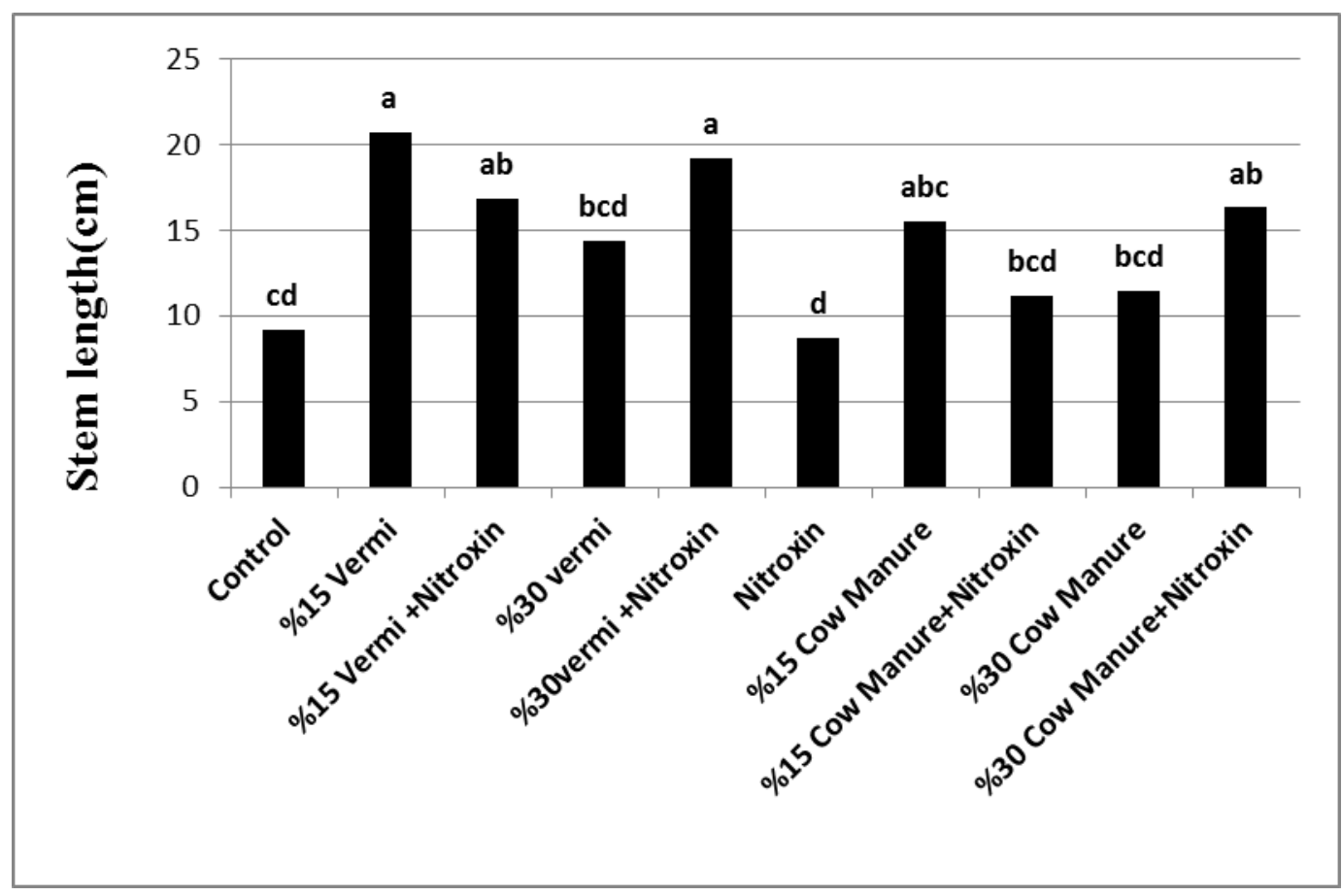

Figure 5. The average of stem elongation in four replications

NOTE: Control $=T 1,15 \%$ Vermi $=T 2,15 \%$ Vermi. Nitroxin $=T 3,30 \%$ Vermi $=$ T4, 30\%Vermi. Nitroxin=T5, Nitroxin=T6, 15\% Cow Manure=T7, 15\% Cow Manure. Nitroxin=T8, 30\% Cow Manure $=$ T9, 30\% Cow Manure. Nitroxin=T10.

Martens et al. (1992) and Hendrix et al. (1994) revealed that the higher yields in plants may be due to the fact that vermicompost supplies direct available nutrients such as nitrogen for the plants and improves the proportion of water table of the soil. Channabasanagowda et al. (2008), have also shown that the differential action of vermicompost may be because of the fact that the vermicompost has the slow release of nitrogen due to slow mineralization which helps in availability of nutrients to the plants throughout the growth of the plant and thus resulting in higher yields. Ismail (1995) reported higher yield in bhendi, chillies, watermelon and paddy and number of canes per hill, internodes distance, stem length, shoot length, cane yield and quality were observed when they were exposed to different concentration of vermicompost than the farm yard manure. Arancon et al. (2004) reported that the differential response of plants to different doses of vermicompost might be due to the production of growth-promoting substances in lesser quantity by lower doses of vermicompost than higher doses. Singh et al. (2008), showed that increasing in vermicompost dose from 2.5 to $7.5 \mathrm{t} \mathrm{ha}^{-1}$ increased all growth characteristics significantly, but vermicompost dose beyond $7.5 \mathrm{t}$ $\mathrm{ha}^{-1}$ could not influence these characteristics significantly. However, the growth of plants with vermicompost at $7.5 \mathrm{t} \mathrm{ha}^{-1}$ was significantly at par with that of $10 \mathrm{tha}^{-1}$ indicating that this dose of $\mathrm{VC}\left(7.5 \mathrm{t} \mathrm{ha}^{-1}\right)$ was enough for supplying the desirable amount of growth-promoting substances for higher growth and fruit yield of strawberry. 


\section{The fresh and dry weight of root and shoot (gr)}

The comparison of the root and shoot mean weight using the Duncan test at 5\% (Table 1) indicated that the fresh weight of roots in the treatments with $15 \%$ vermicompost and two levels of the 30 and $15 \%$ vermicompost mixed with Nitroxin made a significant difference to the control and other treatments, so that these treatments caused the greatest positive impact on the fresh weight of roots. The comparison of treatments showed significant difference in root dry weight just by the treatment of $30 \%$ vermicompost mixed with Nitroxin compared to all other treatments. It was also observed positive effect on the root dry weight by all treatments compared to the control. Moreover, the treatment of $30 \%$ vermicompost mixed with Nitroxin showed the greatest positive impact. Significant difference was observed for shoot fresh weight by the treatment of $30 \%$ vermicompost mixed with Nitroxin with all other treatments. It showed that the most positive effects were related to this treatment.

Table 1. The effect of fertilizer treatments on the growth characteristics of Asparagus

\begin{tabular}{|c|c|c|c|c|}
\hline Treatment & fresh weight(gr) & $\begin{array}{r}\text { Root dry } \\
\text { weight(gr) }\end{array}$ & $\begin{array}{r}\text { Stem fresh } \\
\text { weight }(\mathrm{gr})\end{array}$ & $\begin{array}{l}\text { Stem dry } \\
\text { weight(gr) }\end{array}$ \\
\hline Control & $0.37 b$ & $0.24 \mathrm{c}$ & $0.02 b c$ & $0.03 \mathrm{c}$ \\
\hline $15 \%$ Vermi & $4.42 \mathrm{a}$ & $1.002 b c$ & $1.4 \mathrm{~b}$ & $0.12 \mathrm{ab}$ \\
\hline $15 \%$ Vermi. Nitroxin & $3.2 \mathrm{a}$ & $0.82 b c$ & $0.25 b c$ & $0.11 \mathrm{ab}$ \\
\hline $30 \%$ Vermi & $1.035 \mathrm{~b}$ & $0.8 \mathrm{c}$ & $0.7 \mathrm{bc}$ & $0.09 b c$ \\
\hline $30 \%$ Vermi. Nitroxin & $4.2 \mathrm{a}$ & $1.025 \mathrm{a}$ & $2.7 \mathrm{a}$ & $0.17 \mathrm{a}$ \\
\hline Nitroxin & $0.39 b$ & $0.31 b c$ & $0.42 b c$ & $0.03 \mathrm{c}$ \\
\hline $15 \%$ Cow Manure & $0.15 b$ & $0.52 b c$ & $0.8 \mathrm{bc}$ & $0.07 \mathrm{bc}$ \\
\hline $15 \%$ Cow Manure. Nitroxin & $0.16 b$ & $0.39 \mathrm{~b}$ & $0.6 \mathrm{bc}$ & $0.07 \mathrm{bc}$ \\
\hline $30 \%$ Cow Manure & $0.23 b$ & $0.23 b c$ & $0.6 \mathrm{bc}$ & $0.08 \mathrm{bc}$ \\
\hline 30\%Cow Manure. Nitroxin & $0.55 b$ & $0.69 \mathrm{c}$ & $0.17 \mathrm{bc}$ & $0.1 \mathrm{bc}$ \\
\hline
\end{tabular}

Means within the column with the same letter are not significantly different by Duncan multiple range test at $\mathrm{p} \leq 0.05$.

NOTE: Control $=\mathrm{T} 1,15 \%$ Vermi=T2, 15\%Vermi. Nitroxin=T3, 30\% Vermi=T4, 30\%Vermi. Nitroxin=T5, Nitroxin=T6, 15\% Cow Manure=T7, 15\% Cow Manure. Nitroxin=T8, 30\%Cow Manure $=\mathrm{T} 9,30 \%$ Cow Manure. Nitroxin=T10.

Shoot dry weight showed similar results to shoot fresh weight. Rivera-Cruz et al. (2008) showed that the shoot and root biomass of banana significantly increased by the preparation of bio-fertilizers, using either poultry manure (PM) or banana waste (BW) as the carrier for the bacterial (Azospirillum, Azotobacter) inoculant. They observed positive effects on the growth of banana by the application of both biofertilizers. It seemed to be due to the supply of nutrients to the crop and both biofertilizers can be considered potentially useful as inoculant carriers of PGPR but the usefulness of BW appears to be restricted to moderate doses of application. In this study, the seed germination were not stopped in the organic fertilizer and biofertilizer treatments, however a reduction was observed when these compared with the control. Nevertheless, the vermicompost could improve the vegetable features of root and stem from a few number seedlings. This may be due to a highly fertile, finely divided peat-like material with high porosity, aeration, water-holding capacity and low $\mathrm{C}: \mathrm{N}$ ratios. In fact, the properties listed lead to the better water absorption and consequently the absorption and transport of nutrients in the root zone. Therefore, the significant differences were observed between some treatments of vermicompost regarding the elongation and root 
and shoot weight. These results can be supported by the finding of Edwards and Burrows (1988), Werner and Cuevas (1996), Gupta et al. (2014), Subler et al. (1998) and Tucker (2005).

\section{Conclusions}

There were significant differences between control treatment and the other fertilizer treatments. The germination percentage was higher in control treatment compared with the others. The highest germination percentage was related to the mixture of $30 \% \mathrm{cow}$ manure with Nitroxin and the lowest one was related to the $15 \%$ cow manure. The effect of $15 \%$ vermicompost on the germination percentage was higher than $30 \%$ vermicompost. Significant differences in mean germination time in comparison with the control treatment were related to the fact that $15 \%$ vermicompost had the highest mean germination time and the highest rate observed in the control of seed germination of the asparagus. The comparison of fertilizer treatments showed $30 \%$ cow manure mixed with Nitroxin treatment has the highest rate of germination and $15 \%$ cow manure resulted in lower germination rate than other treatments. Significant differences of root length in relation to other treatments were produced by treatments of $15 \%$ vermicompost and $30 \%$ vermicompost mixed with Nitroxin that caused the greatest impact on root length also the effect was higher by $15 \%$ vermicompost treatment alone but at the level of $30 \%$ was higher the effect of vermicompost mixed with Nitroxin. However, all fertilizer treatments caused increasing the shoot length but the highest impact and significant differences compared with the control have observed by treatments with $15 \%$ vermicompost, 30 and 15\%vermicompost mixed with Nitroxin and $30 \%$ of cow manure mixed with Nitroxin. At the level of $15 \%$ vermicompost and cow manure treatments alone but at level of $30 \%$ the treatments of cow manure and vermicompost mixed with Nitroxin showed the impact of higher elongation of stems. Significant differences were observed in root fresh weight by the treatments of $15 \%$ vermicompost, mixture of 30 and $15 \%$ vermicompost and Nitroxin than control and other treatments and while fresh weight of roots was reduced by mixed treatment of $15 \%$ vermicompost with Nitroxin, but at the level of $30 \%$ the mixed treatment showed higher impact. Positive effect and significant difference was not observed for root fresh weight between treatments of Nitroxin and cow dung alone or in combination, however, these treatments caused greater influence on root dry weight than control. Significant differences were observed at root dry weight by combined treatments of $30 \%$ vermicompost also $15 \%$ cow manure with Nitroxin in general. Root dry weight increased by fertilizer treatments similarly in the fresh and dry weight of shoot and the maximum effect was obtained from $30 \%$ vermicompost mixed with Nitroxin and the level of $15 \%$ non-mixed treatment but at the level of $30 \%$ combined treatment a greater impact was observed.

\section{REFERENCES}

[1] Alves, W.L., Passoni, A.A.(1997): Compost and vermicompost of urban solid waste in Licania tomentosa (Benth) seedlings production to arborization. - Pesqui Agropecu Bras 32:1053-1058. 
[2] Arancon, N .Q., Lee, S., Edwards, C. A., Atiyeh, R. M.(2003): Effects of humic acids and aqueous extracts derived from cattle, food and paper-waste vermicomposts on growth of greenhouse plants. - Pedobiologia 47: 741-744.

[3] Arancon, N.Q., Edwards, C.A., Bierman, P., Welch, C., Metzer, J.D.(2004): Influence of vermicomposts on field strawberries: effect on growth and yields. - Bioresource Technology 93:145-153.

[4] Atiyeh , R. M., Dominguez, J., Subler, S., Edwards, C. A. (2000); Biochemical changes in cow manure processed by earthworms (Eisenia andreii) and their effects on plantgrowth. - Pedobiologia 44,709-724.

[5] Atiyeh, R. M., Arancon, N .Q., Edwards, C .A., Metzger, J .D. (2001): The influence of earthworm-processed pig manure on the growth and productivity of marigolds. Bioresource Technology 81:103-108.

[6] Baca, M.T., Delgado I C, Sanchez-Raya A J, Gallardo-Lara F. (1990): Comparative use of cress seed germination and physiological parameters of Helianthus annuus L. to assess compost maturation. - Biol. Wastes 33:251-261.

[7] Buckerfield, J. C., Flavel ,T., Lee, K .E., Webster, K. A. (1999): Vermicomposts in solid and liquid form as plant-growth promoter. - Pedobiologia 43: 753-759.

[8] Channabasanagowda, N. K., Patil ,B. N., Patil, J. S., Awaknavar, B. T., Ninganur, R.H. (2008): Effect of Organic Manure on Growth, Seed Yield and Quality of Wheat. Karnataka Journal of Agricultural Sciences 21:366-368.

[9] Edwards, C. A. (1983): Utilization of earthworm composts as plant growth media. - In: Tomati, U., Grappelli, A. (Eds.) International Symposium on Agricultural and Environmental Prospects in Earthworm, Rome, Italy, pp. 57-62.

[10] Edwards,C .A., Burrows, I. (1988): The potential of earthworm composts as plant growth media. - In: Edwards, C.A., Neuhauser, E.F. (Eds.) Earthworms in Environmental and Waste Management. SPB Academic Publ. b.v, The Netherlands, pp. 211-220.

[11] Edwards, C .A., Dominguez, J., Arancon, N. Q.(2004): The influence of vermicomposts on plant growth and pest incidence. - In: Mikhail, W.Z.A, Shakir, S.H. (Eds.) Soil Animals and Sustainable Development, pp. 397-420.

[12] Ellis, R. H., Roberts, E. H. (1981): The quantification of ageing and survival in orthodox seeds. - Seed Science and Technology 9: 377-409.

[13] Esitken, A.,Ercisli, S., Karlidag, H., Sahin, F. (2005): Potential use of plant growth promoting rhizobacteria (PGPR) in organic apricot production. - In: Proceedings of the International Scientific Conference of Environmentally Friendly Fruit Growing, TartuEstonia, 7-9 September, pp. 90-97.

[14] Garraway, J .L., Ramirez, AME. (1982): Phenolic acids in pig slurry subjected to various treatment processes. - Journal of the Science of Food and Agriculture 33,697-705 Gowing DP and Leeper.

[15] Gupta, R., Yadav, A., Garg, V. K.(2014): Influence of vermicompost application in potting media on growth and flowering of marigold crop. - International Journal of Recycling of Organic Waste in Agriculture 3- 47.

[16] Hendrix, P. F., Callaham, M. A., James, S. W.(1994): Ecology of nearetic earthworms in the Southern USA-I. Characteristics of diplocardia longa surface casts in grass, hardwood and pine micro habitats on the lower pied mount of Georgia. - Megdrilogica 5: 45-51.

[17] Ievinsh, G. (2011): Vermicompost treatment differentially affects seed germination, seedling growth and physiological status of vegetable crop species. - Plant Growth Regulation 65:169-181.

[18] Ismail, S. A. (2005): The Earthworm Book. - Other India Press, Mapusa, Goa, India. pp. 73-74.

[19] Jimenez E I, Garcia, V.P. (1989): Evaluation of city refuse compost maturity: a review. Biological Wastes 27: 114-115.

[20] Lind, K., Lafer,G., Schloffer, K., Innerhoffer, G., Meister, H.(2003): Organic Fruit Growing. - CABI Publishing, Wallingford, UK. 
[21] Marambe, B., Ando, T. (1992): Phenolic acids as potential seed germination inhibitors in animal-waste composts. - Soil Science and Plant Nutrition 38:723-733.

[22] Marambe, B., Nagaoka, T., Ando, T. (1993): Identification and biological activity of germination-inhibiting long-chain fatty acids in animal-waste composts. - Plant Cell Physiology 34:605-612.

[23] Martens, D.A., Johanson, J. B., Frankenberger, W. T.(1992): Production and persistence of soil enzymes with repeated addition of organic residues. - Soil Science 153: 53-61.

[24] O'Connell, P. F. (1992): Sustainable agriculture-a valid alternative. - Outlook Agriculture 21: 5-12.

[25] Rivera-Cruz, M .D .C., Narci'a, A .T., Ballona, G. C., Kohler, J., Caravaca, F., Rolda'n, A . (2008): Poultry manure and banana waste are effective biofertilizer carriers for promoting plant growth and soil sustainability in banana crops. - Soil Biology and Biochemistry 40: 3092-3095.

[26] Rodriguez, H., Fraga, R.(1999): Phosphate solubilizing bacteria and their role in plant growth promotion. - Biotechnology Advances 17: 319-339.

[27] Roy, S., Arunachalam, K., Dutta, B.K., Arunachalam, A.(2010): Effect of organic amendments of soil on growth and productivity of three common crops viz. Zea mays, Phaseolus vulgaris and Abelmoschus esculentus. - Applied Soil Ecology 45:78-84

[28] Singh, A., Jain, A., Sarma, B.K., Abhilash, P.C., Singh, H.B.(2013): Solid waste management of temple floral offerings by vermicomposting using Eisenia fetida. - Waste Management 33:1113-1118

[29] Singh, R., Sharma, R.R., Kumar, S., Gupta, R. K, Patil, R. T. (2008): Vermicompost substitution influences growth, physiological disorders, fruit yield and quality of strawberry (Fragaria x ananassa Duch). - Bioresource Technology 99: 8507-8511.

[30] Sturz, A .V., Nowak, J. (2000): Endophytic communities of rhizobacteria and the strategies required to create yield enhancing associations with crops. - Applied Soil Ecology 15: 183-190.

[31] Subler, S., Edwards, C.A., Metzger, J. (1998): Comparing vermicomposts and composts. - Biocycle 39:63-66

[32] Sudhakar, P., Chattopadhyay, G. N., Gangwar, S. K., Ghosh, J.K. (2000): Effect of foliar application of Azotobacter, Azospirillum and Beijerinckia on leaf yield and quality of mulberry (Morus alba). - Journal of Agricultural Science 134: 227-234.

[33] Tucker, P. (2005): Co-composting paper mill sludges with fruit and vegetable wastes. Dissertation. University of Paisley, Paisley

[34] Vessey,J .K. (2003): Plant growth promoting rhizobacteria as biofertilizers. - Plant and Soil 255: 571-586.

[35] Tomati, U., Grappelli, A., Galli, E. (1987): The presence of growth regulators in earthworm-worked wastes. - In: Bonvicini Paglioi, A.M., Omodeo, P. (Eds.) On Earthworms. Proceedings of International Symposium on Earthworms. Selected Symposia and Monographs, Unione Zoologica Italiana, 2, Mucchi, Modena, pp. 423-435.

[36] Warman, P. R. (1999b) Evaluation of seed germination and growth tests for assessing compost maturity. - Compost Science and Utilization 7 (3):33-37.

[37] Warman,,P.R., AngLopez, M. J. (2010):Vermicompost derived from different feedstocks as a plant growth medium. - Bioresource Technology 101:4479-4483.

[38] Werner, M., Cuevas, R.(1996): Vermiculture in Cuba Biocycle. vol. 37(6). - JG Press, Emmaus, PA, pp. 61-62

[39] Yadav, A., Garg, V. K.(2015): Influence of vermi-fortification on chickpea (Cicer arietinum L.) growth and photosynthetic pigments. - International Journal of Recycling of Organic Waste in Agriculture 4:299-305

[40] Zaller, J.G. (2007): Vermicompost in seedling potting media can affect germination, biomass allocation, yields and fruit quality of three tomato varieties. - European Journal of Soil Biology 43:332-336. 